\title{
Augmented Reality Trends in Teaching English Tenses: The Case of Non-English Education Students
}

YELIA $^{1 *}$, DONY EFRIZA $^{2}$, AND SANTI HENDRAYANI $^{3}$

\begin{abstract}
The purpose of this study was to examine a classroom action research about using augmented reality media to improve non-English students' tenses mastery. The study was carried out in two cycles and each cycle consists of four stages, including plan, action, observation, and reflection. The participants of the study were a class of students of economic education study program, faculty of teacher training and education at a public university in Jambi who were taking English subject. The data of the study were taken from a test and observations in collecting the data. The results of the data analysis indicated that there was an increase from the first cycle to the second cycle. Moreover, the research results showed that: 1) augmented reality created a good atmosphere in the teaching and learning activities; 2) augmented reality made the students understand the use of tenses easily; and 3) the students became more active and attractive in the teaching and learning activities. It can be concluded that the use of augmented reality can improve students' tenses mastery.
\end{abstract}

\section{Keywords}

Augmented reality, media, tenses mastery

${ }^{1}$ senior lecturer at the English Education Department of the Faculty of Education and Teacher Training,

Universitas Jambi, Indonesia; Correponding email: davizayelia@gmail.com

${ }^{2}$ lecturer at the English Education Department of the Faculty of Education and Teacher Training, Universitas Jambi, Indonesia

${ }^{3}$ senior lecturer at University of Nurdin Hamzah, Jambi, Indonesia. 


\section{IRJE | Indonesian Research Journal in Education | | Vol. 5| No. 2|Dec | Year 2021|}

\section{Introduction}

It is undeniable that, as a global language, English is used as a tool of communication in the world of trade and commerce. Accordingly, having good knowledge of English is very important to make communication in business become more effective and to get success in any career as well. In line with the importance of English, it becomes one of the compulsory subjects at economic study program at universities. In order to be able to communicate effectively, and to get a good career after finishing their study, all students of economic program should master English including the use of English tenses. The mastery of English tenses is very important to make communication become more effective since they are the most important parts of English language. When people want to say or speak something, or to write a sentence clearly to other people, they need to use the appropriate form of tenses. The use of appropriate forms of tenses will help others to be able to get the clear idea of the speakers or the writers. Tense is a verb form that indicates the time when an action, event, or state takes place (Swan, 2005). English language has three main time divisions- past, present and future expressed by the tenses. Each tense is subdivided to express other aspects within its general time. For example, adding -ed to the verb "talk", to form "talked", indicates that the event showed by the verb took place before the present time. Another example, using the -ing form indicates that an action is completed or still ongoing, as in "We are discussing an interesting topic of business." However, English typically uses the "-ing" form of verbs to indicate ongoing processes, as in "They are building an office."

However, the researchers found that most students in a class of Economic Education Study Program at the research site were not able to use the appropriate tenses when undertaking spoken or written communication. For example, a student wrote "I will going to the market." He used the wrong verb to show the action that he will do in the future time. Another example, a student wrote "I do not send you my reportyesterday." He actually had to use $\boldsymbol{d i d}$ rather than $\boldsymbol{d o}$ in that sentence. For that condition, it was important to improve students' mastery of English tenses by implementing a classroom action research (CAR). It is a scientific and systematic approach to investigation that enables teachers or lecturers to find effective solutions to problems they confront in everyday life (Stringer, 2007).

Students' mastery of English tenses can be supported by using teaching media in the process of teaching and learning. Teaching media will help teachers to deliver learning materials to students to reach certain learning goals and help students to understand learning materials easily. Arif (2003) says that media are an intermediary tool or delivery of messages from the sender to the receiver of the message. In other words, learning media is a tool used to deliver teaching materials from the teachers to the learners. In order to solve the problem, our research team decided to use technology media, namely augmented reality.

Recently, the development of information and technology enables people to obtain information easily. Augmented reality is one way that can be used to send information to others in an interesting way by utilizing the development of Science and Technology and it is one of the newest movements that appears as a result of the dominance of technology particularly mobile application, in the last few year. Augmented reality (AR) is a technology that combines two-dimensional and or three-dimensional virtual objects into a real 


\section{IRJE | Indonesian Research Journal in Education | | Vol. 5| No. 2|Dec | Year 2021|}

three-dimensional environment. So it can be concluded that augmented reality (AR) is the emergence of holographic characters that are one with the real world. With augmented aspects and features, it can enhance learning abilities like problem - solving, collaboration, and creation to better prepare students for the future.

Therefore, AR provides students with opportunities to deepen their knowledge within several areas, including reading, working with numbers, spatial concepts, playing, content creation, real life environments and scenarios. The purpose of this study was to examine a classroom action research about using augmented reality media to improve non-English students' tenses mastery. This study was expected to give some benefits to English teachers as it can be references for them when teaching English to non-English students. Overall, this study was conducted to explore the following research question: How do augmented reality media improve students' tenses mastery?

\section{Literature Review}

\section{Basic tenses in English}

Doing communication is very important in everyday life, at work, and nearly any time people interact with each other. People need to communicate to know and understand other people, to build relationship, and to share information. Communication is built by using sentences. An effective communication is indicated by sentences with appropriate tenses and elements. There are three basic tenses in English; they are simple present tense, simple past tense, and simple future tense. While there are two elements of a sentence, they are phrases and clauses. Phrases ware two or more words that function as a group while clause is a part of a sentence which contains a subject and a verb usually joined to the rest of a sentence by using conjunction (Swan, 2005).

Phrase is a grammatical unit that is needed to build a clause. There are 5 types of phrases: verb phrase, noun phrase, adjective phrase, adverb phrase, and prepositional phrase. Verb phrase is a phrase that functions as a predicate, e.g. have come, had thought, was left, will be climbing. Noun phrase is a phrase that functions as an object or noun, e.g. a good flight, his crew. In the example, the noun phrase is a noun and is preceded by a determiner or adjective.

Noun phrases can also be pronoun. Adjective phrase is a phrase that functions as an adjective, e.g. so busy, very late. Adjective phrase is a phrase that contains adjectives and can also be described with levels such as very and so. Adverb phrase is a phrase that serves as a description, e.g. very quickly, almost certainly. The adverb can also be preceded by a description of the level, for example, almost. Prepositional phrases are a phrase that functions as a preposition, e.g. after lunch, on the aircraft.

Clause is a syntactic unit that is above the unit of phrase and below the unit of sentence, in the series of predictive words. This means that in the construct there are components in the form of words or phrases that function as predicates, and the others function as subjects, objects and so on (Chaer, 2009). The following are the examples of clauses. 


\section{IRJE | Indonesian Research Journal in Education | | Vol. 5| No. 2|Dec | Year 2021|}

She looked up the answer
S V
$\mathrm{O}$
We are discussing an interesting topic in the office
$\mathrm{S}$
$\mathrm{V}$
$\mathrm{O}$ ADV

Notes:

$\mathrm{S}=$ Subject

$\mathrm{V}=\mathrm{Verb}$

$\mathrm{O}=$ Object

$\mathrm{Adv}=$ Adverb

Sentence is a group of words that expresses a statement, command, question, or exclamation. It consists of one or more clauses and usually has at least one subject and one verb. In writing form, a sentence is begun with capital letter and ended with a full stop (.), question mark (?), or exclamation mark (!). Types of sentence are simple sentence, compound sentence, complex sentence, sentences with relative clause and compound complex sentence. Simple sentence is a sentence that is built by a clause, for example: The little boy langhed. Compound sentence or a combined sentence is a sentence that is built from two clauses put together with a conjunction such as for, and, nor, but, or, yet and so, for example: Jane put the glass vase on the table and her mother picked it up. Complex sentence or compound sentence is a sentence consisting of main clauses and derivative clauses, for example: Harry was only of teen when his mother sent him away to school. Sentence with relative clause is a sentence with derivative clauses that add information to the noun phrase, for example: I brought the cookies that are on the plate.Compound complex sentence is the combination of compound and complex sentences. This sentence has at least two main clauses and one derivative clause, for example: I'll leave a message for the plumber (Main Clause) but I'm not sure (Main Clause) that he'll get it (Dep. Clause).

Based on the use of function of the predicate, sentences are divided into two, namely verbal sentences and nominal sentences. Verbal sentence is a sentence which predicate is a verb, for example: She is sleeping. Verbal sentence can be divided into positive verbal sentence the so called affirmative sentence, negative verbal sentence, and interrogative verbal sentence. While nominal sentence is a sentence that is predicated not by a verb, but of a noun, an adjective, a number, a pronoun, or an adverb, for example: I am a doctor. Like verbal sentence, nominal sentence is also divided into positive nominal sentence, negative nominal sentence, and interrogative nominal sentence.

\section{Augmented reality media in language learning}

In consequence to the development of technologies and the immensity of smartphones, mobile-assisted language learning has been developing fast. Much research was conducted, including Rosell-Aguilar (2017), Zhang and Pérez-Paredes (2021). They promoted the use of mobile tools in English language education, like WeChat- instant messaging applications (Wu, 2017, 2018) and self-developed learning software (Wang et al., 


\section{IRJE | Indonesian Research Journal in Education | | Vol. 5| No. 2|Dec | Year 2021|}

2009). As various existing augmented reality software relies on the use of mobile technology, it is considered one type of mobile learning (Greenwood \& Wang, 2018). To be more specific, augmented reality in English language education can be grouped into the scope of mobile-assisted language learning, which enables the continuity or spontaneity of access and interaction across various language teaching and learning contexts (Kukulska-Hulme \& Shield, 2008). Other than conventional classroom learning, Augmented Reality can combine the real scene perceived by the learner with the virtual scene which is generated by mobile devices, so as to build a semi-realistic world and to intensify students' motivation to learn a foreign language (Liu \& Tsai, 2013).

Augmented reality is a term used to describe the form of real objects produced in a computer. It is "a combination of technologies that superimposes computer-generated content over a real word environment" (Wang et al. 2018, p. 1391), which interactively connects the real and the virtual worlds and appears at three dimensions (Azuma, 1997). An augmented reality application can contain various functions, both for interaction or display (Bacca et al., 2014). One example of the augmented reality is when we are in a museum that uses the application contained in the museum, we can scan the barcode at the base of the statue and the application will show images of the statue with fully interactive descriptions. Ward (2012) states that augmented reality can also be used to display museum maps that show different works, this allows us to follow maps of these locations.

Augmented reality is a system that combines the real world and computer graphics. Husni and Rokhmat (2008) and Amin and Govilkar (2015) say that the purpose of augmented reality is to add real-world understanding and information where the augmented reality system takes the real world as a basis and combines several technologies by adding contextual data so that one's understanding becomes clearer. Meanwhile, augmented reality is a technology that can be exploited in current developments so that the information contained can be well absorbed.

\section{Methodology}

This research was conducted to solve students' problems in using English tenses and was carried out in accordance with the stages of the cycles in the classroom action research (CAR). CAR is a method of finding out what works best in teachers' own classroom so that they can improve the quality of the process of learning and students' achievement as well. The function of CAR as a tool is to solve the problem in the classroom and as in service training. Doing a CAR allows teachers know a great deal about good teaching in general (e.g., Ab Aziz et al., 2012; Ajipramuditya, 2013; McKeachie, 1990; Chickering \& Gamson, 1987; 1996).

This study began from lecturer's reflection of the learning process and students' learning achievements and the result of the reflection were used as the basic data to plan the research. The process of reflection takes with a cycle to follow the steps such as teach, self-cases the effect of our teaching, learning, consider new ways of teaching that can improve the quality of learning practice. The lecturers and the researchers, then, set some plans of the study and they continued to the next stages: acting, observing, and reflecting 


\section{IRJE | Indonesian Research Journal in Education | | Vol. 5| No. 2|Dec | Year 2021|}

stages. The stages above were carried out repeatedly and continuously until a certain quality of success can be achieved (Wibawa, 2004).

This study was conducted at the economic education study program, faculty of teacher training and education at a public university in Jambi. The students learnt English as a compulsory subject at their program conducted in the the first semester. They were fresh graduates from senior and vocational high schools. In the learning process, they had different abilities in learning the materials. In conducting the study, the lecturer and researchers collaborated in a team work. In this way, it was hoped that the validity of the data collected could be reached. This study needed collaboration since it had the capability for exchanging ideas across disciplines learning new skills, access to finding higher quality of result, benefit, and personal factors such as fun and pleasure. Collaborative research can be defined as researchers indulge themselves toward coordination between researchers, institution, organizations, and communities.

There were two types of data taken in this study, including students' achievements in learning English tenses and the description of the situation, condition and process of learning activities during the study conducted. Students' achievement is the measurement of the amount of academic content a student learn in a given time schedule. Each instruction level has specific standards or goals that educators must teach their students properly, students' levels of self - efficacy, self-control, motivation, and impact levels of achievement. The data were collected through participant observation.

There were two techniques used in this study, namely qualitative analysis and quantitative analysis. Quantitative analysis was used to analyze the data of students' achievement, while qualitative analysis was used to analyze the data collected from observations. Data analysis was carried out through the following stages: 1) classifying the data to make it systematic; 2) reducing and omitting irrelevant and unnecessary data; 3) comparing data that had been classified; and 4) interpreting the data. To avoid subjectivity, researchers utilized triangulation. The pre- and post-test can be a valuable diagnostic tool for more effective teaching. The function of pre- and post-test can be the following ways to identify the best student in the classroom, topics which the students already know, topics which the students don't know and have not learned.

\section{Findings and Discussion}

Based on the results of observation and field notes of four-week implementation of the action, it could be concluded that the use of augmented reality can motivate students to focus on teaching materials. This is because the use of augmented reality in teaching English is still a new issue. In other words, by using the media of augmented reality, students' attention can be more focused on the materials learned and become an effort to increase their understandings of lecture material, and through practicing it also increases their ability to use tenses properly and correctly. Even so, the research team found that the results achieved were good. Therefore, further efforts should be made in the use of media. Oral exercises in the form of language games are very useful to motivate students. The term of "language games "refers to the models of a primitive language that invents to clarify the working of language in general. 


\section{IRJE | Indonesian Research Journal in Education | | Vol. 5| No. 2|Dec | Year 2021|}

Hadfield (2004) defines a game as an activity with rules, a goal and an element, not only for the language practice they provide, but also for the therapeutic effect they have. According to Richard-Amato (1998) games are divided into non-verbal games, boardadvancing games, word- focus games, treasure hunts, and guessing games. They can be used at any stages of a class to provide an amusing and challenging respite from other classroom activity about their English class. In oral exercises, some activities were given, including Jigsaw, role play, information gap, simulation and contact assignment. However, the implementation was not really like what had been formulated in the planning stage.

At the planning stage, oral exercises were set for each topic given in the form of language games. Structured writing exercises as an online homework were given in the form of assignments and the students had to fill in the blank in the specified time. This exercise could also motivate students to use online technology to communicate in writing. Therefore, it was also determined that in the second cycle, this kind of training was also continued. To be similar with the first cycle, the second cycle also took place over 4 weeks and also went through four stages consisting of planning, action, observation, and reflection.

After completing the second cycle, in the following week, the English post-test on tenses took place to figure out the progress achieved. The post-test results showed the average score was 90. The research team again discussed all actions observed in this round with several parties involved in the economic education study program environment. From the results of the discussion, it could be concluded that there was an increase in students' learning motivation and this indicates an increase in understanding and using English tenses correctly both in oral and written forms. The result of the post-test significantly increased.

Thus, it can be concluded that the use of augmented reality media as well as of oral exercises and structured writing exercises were able to motivate students to pay attention to lectures. It also increased students' understanding and ability in using tenses correctly, both oral and written forms. The results of the pre-test looking at the ability of students were very unsatisfactory. The pre-test mean score showed that the average of the pre-test score was 35. Also, there was an increase of motivation to paying attention to lessons, understanding, and using tenses correctly, both oral and written forms. It turned out that the observations showed an increase in motivation and understanding, and this was supported by the results of the post-test which showed a significant increase in ability. The average score of the test in the first cycle was 68 and 90 in the second cycle. The average score of this post-test showed an increase of 22 points, a very sharp increase. The post-test data of cycle 1 and 2 can be seen in the table below: 


\section{IRJE | Indonesian Research Journal in Education | | Vol. 5| No. 2|Dec | Year 2021|}

Table 1. Students' average value in cycle 1 and gycle 2

\begin{tabular}{llllll}
\hline ID & Test II & Test III & ID & Test II & Test II \\
\hline S1 & 60 & 88 & S16 & 60 & 87 \\
S2 & 76 & 92 & S17 & 60 & 88 \\
S3 & 68 & 90 & S18 & 65 & 91 \\
S4 & 65 & 88 & S19 & 72 & 90 \\
S5 & 72 & 94 & S20 & 88 & 97 \\
S6 & 81 & 97 & S21 & 63 & 88 \\
S7 & 60 & 85 & S22 & 66 & 90 \\
S8 & 90 & 99 & S23 & 72 & 90 \\
S9 & 60 & 84 & S24 & 63 & 89 \\
S10 & 64 & 88 & S25 & 72 & 90 \\
S11 & 60 & 87 & & \\
S12 & 66 & 90 & & \\
S13 & 64 & 88 & & \\
S14 & 68 & 90 & & \\
S15 & 65 & 90 & & \\
& Total $\left(\sum x\right)=1700$ and 2250 & \\
\hline
\end{tabular}

The increase of the students' ability to use the correct tenses can be seen from the pre-test answers. Most students were less aware of the use of the 2 nd tense verbs in the past tense form. From the data of post-test answers, students' mistakes have been considerably reduced. In connection with the use of augmented reality media and LED/In-focus TV, this activity had become very interesting. Besides, it also saved time so that lecturers spent plenty of time to pay attention to and interact with students. The lecturers were able to control the class better; choose transparency/impressions; stop when someone asked or continued with the explanation; arrange the order of transparency or replay what needs to be among those previously shown; and observe student reactions. Based on the results of the study, the use of augmented reality media among students was effective enough to improve students' tenses mastery. Before and after using augmented reality media in learning tenses, the students' accuracy and mastery were significantly different.

In addition, through verbal exercises using language games and structured writing exercises, tenses exercises emphasized more on consciousness-raising rather than practices. This type of classroom activity, according to Fotos and Ellis (1991), is more effective in improving grammar skills, including tenses. This is supported by the acquisition of the language being studied because grammar teaching is equipped with situational tasks so that grammar knowledge not only become mere knowledge, but also enable students to be able to use it properly, both in oral and written forms. Students can participate interactively and interact with knowledge more authentically. They can also become active learners and are able to interact with their learning environment. 


\section{IRJE | Indonesian Research Journal in Education | | Vol. 5| No. 2|Dec | Year 2021|}

\section{Conclusion}

The conclusion of the study can be drawn as regards to describe how the use of augmented reality media improves students' tenses mastery. English is important in the world of trade and commerce. So it becomes one of the compulsory subjects at the research site. Some problems occur in English learning including students' mastery of tenses. This study showed that students' tenses mastery can be improved by teachers through a classroom action research by using augmented reality media. For the students' achievement, the result of data analysis showed that the mean score in the first cycle was 68 and increased to 90 in the second cycle. Moreover, the results showed that: 1) augmented reality created good a atmosphere in the teaching and learning activities, 2) augmented reality made the students understand the use of tenses easily, and 3) the students became more active and attractive in the teaching and learning activities.

\section{Disclosure statement}

No potential conflict of interest was reported by the authors.

\section{References}

Ab Aziz, K., Ab Aziz, N. A., Yusof, A. M., \& Paul, A. (2012). Potential for providing AR elements in special education via cloud computing. Proc. Eng., 41, 333-339.

Akçayir, M., \& Akçayir, G. (2017). Advantages and challenges associated with AR for education: a systematic review of the literature. Educ. Res. Rev., 20, 1-11.

Ajipramuditya, T, A. (2013). Analysis of implementation comparison of performance vuforia and in $2 a r$ augmented reality sdks on mobile advertising applications. Bandung: Telkom Institute of Technology.

Arif. S. 2003. Media pendidikan: Pengerttian, pengembangan, dan pemanfaatannya. Jakarta: PT. Grafindo Persada.

Amin, D., \& Govilkar, S. (2015). Comparative study of AR Sdk's. Int. J. Comput. Sci. Appl., 5, 11-26. doi: $10.5121 /$ ijcsa.2015.5102

Azuma, R. T. (1997). A survey of augmented reality. Presence: Teleoperators \& Virtual Environ 6(4), 355-385.

Bacca, J., Baldiris, S., Fabregat, R., Graf, S., \& Kinshuk. (2014). AR trends in education: a systematic review of research and applications. Educ. Technol. Soc., 17, 133-149.

Chaer, A. (2009). Pengantar semantik bahasa. Jakarta: Rineka Cipta.

Chickering, A. W., \& Gamson, Z. F. (1987). Seven principles for good practice in undergraduate education. The Wingspread Journal, 9, 1-10.

Fotos, S., \& Ellis, R. (1991). Communicating about grammar: A task-basedapproach. TESOL Quarterly, 25, 605-628. 


\section{IRJE | Indonesian Research Journal in Education | | Vol. 5| No. 2|Dec | Year 2021|}

Greenwood, A. T., \& Wang, M. (2018). Augmented reality and mobile learning: theoretical foundations and implementation. In: Crompton $\mathrm{H}$, Traxler J (eds) Mobile learning and higher education: challenges in context. Routledge, New York, pp 41-55.

Hadfield. (2004). Crossword puzzle as an effective way to teach English vocabulary. Combridge: Combridge University Press.

Husni, E. M., \& Rokhmat, Y. (2008). Perancangan augmented reality volcano untuk alat peraga museum. Bandung: ITB.

Kukulska-Hulme, A., \& Shield, L. (2008). An overview of mobile assisted language learning: from content delivery to supported collaboration and interaction. ReCALL, 20(3), 271-289.

Liu, P. H. E. \& Tsai, M. K. (2013). Using augmented-reality-based mobile learning material in EFL english composition: an exploratory case study. BrJ Edu Technology, 44(1), E1E4.

McKeachie, W. J. (1990). Research on college teaching: the historical background. Journal of Educational Psychology, 82, 189-200.

Richard-Amato, P.A. (1998). Making it happen: Interaction in the second language classroom: From theory to practice. New York: Longman.

Rosell-Aguilar, F. (2017). State of the app: A taxonomy and framework for evaluating language learning mobile applications. CALICO Journal, 34(2), 243-258.

Stringer, E.T. (2007). Action research. California: Sage Publications Inc.

Swan, M. (2005). Practical English usage: Easier, faster reference. New York: Oxford University Press.

Ward, T. (2012). Augmented reality using the titanium starter appcelerator. Birmingham: Packt Publishing Ltd.

Wang, M., Shen, R., Novak, D., \& Pan, X. (2009). The impact of mobile learning on students' learning behaviours and performance: report from a large blended classroom. BrJEdu Techno, 140(4), 673-695.

Wang, M., Callaghan, V., Bernhardt, J., White, K., \& Peña-Rios, A. (2018). Augmented reality in education and training: pedagogical approaches and illustrative case studies. J Ambient Intell HumIzed Comput, 9(5),1391-1402.

Wibawa, B. (2004). Penelitian tindakan kelas. Jakarta: Departemen Pendidikan Nasional. Direktorat Jendral Pendidikan Tinggi.

Wu, J. (2017). Teacher's presence in synchronous mobile chats in a Chinese university. J Asia TEFL, 14(4), 778-783.

Wu, J. (2018). Mobile collaborative learning in a Chinese tertiary EFL context. TESL-EJ, 22(2), 1-15.

Zhang, D., \& Pérez-Paredes, P. (2021). Chinese postgraduate EFL learners' self-directed use of mobile English learning resources. Comput Assist Lang Learn, 34(8), 1128-1153.

Zhang, D., Minjuan, W., \& Wu, J. G. (2020). Design and implementation of augmented reality for english language education. In: Vladimir Geroimenko, Augmented reality in education: A new technology for teaching and learning (pp. 217-234). Springer 


\section{Biographical Notes}

Dr. YELIA, M.Pd is a senior lecturer at the English Education Department of the Faculty of Education and Teacher Training, Universitas Jambi, Indonesia.

DONY EFRIZA, M.Pd is a junior lecturer at the English Education Department of the Faculty of Education and Teacher Training, Universitas Jambi, Indonesia.

SANTI HENDRAYANI, M.Pd. is a senior lecturer at University of Nurdin Hamzah, Jambi, Indonesia. 